\title{
PENGARUH SKARIFIKASI MENGGUNAKAN URIN KAMBING PADA BIJI GAMAL (Gliricida sepium) DENGAN WAKTU PERENDAMAN BERBEDA TERHADAP KUALITAS BENIH
}

\author{
The Effect of Scarification Using Goat Urine for Gamal Seeds (Gliricidia sepium) with Different Time \\ of Soaking on Seed Quality
}

\author{
Holil Pathan Nur, Agung Kusuma Wijaya, Liman, dan Muhtarudin
}

Department of Animal Husbandry, Faculty of Agriculture, University of Lampung

Jl. Prof. Soemantri Brojonegoro No.1 Gedung Meneng Bandarlampung 35145

e-mail : holilpathannur@gmail.com

\begin{abstract}
This study aimed to determine the effect of scarification using goat urine with different soaking time on the quality of gamal seeds (Gliricidia sepium) and determine the best scarification treatment that produces normal sprouts and the best sprouts. This research was conducted in January 2020, located in the Laboratory of Animal Nutrition and Feed, Department of Animal Husbandry, Faculty of Agriculture, University of Lampung. This study used an experimental method using Completely Randomized Design with 5 treatments (control or without soaking, seed soaking for 4, 8, 12, and 16 hours) and 6 replications. Each trial unit received 30 seeds of Gamal. Data analysis was performed using the ANOVA continued by the least significant difference (LSD) test. The results showed that scarification of gamal seeds in goat urine at different times of soaking gave significantly effect $(\mathrm{P}<0.05)$ on germination, normal sprouts, dead seeds and hard seeds, but did not affect on abnormal sprouts and yield attacked by pests. The best scarification treatment for normal sprouts and sprouts rate was soaking for 16 hours, namely $60.00 \%$ and $47.73 \%$, respectively. This results showed the longer soaking the seeds, the higher the germination and normal sprouts.
\end{abstract}

Keywords: Gamal seeds, Goat urine, Scarification, Soaking time

\begin{abstract}
ABSTRAK
Penelitian ini bertujuan untuk mengetahui pengaruh skarifikasi di dalam urin kambing dengan lama perendaman berbeda terhadap kualitas biji gamal dan menentukan perlakuan skarifikasi terbaik yang menghasilkan benih kecambah normal dan daya kecambah terbaik. Penelitian ini dilaksanakan pada bulan Januari 2020, berlokasi di laboratorium Nutrisi dan Makanan Ternak Jurusan Peternakan Fakultas Pertanian Universitas Lampung. Penelitian ini menggunakan metode eksperimen dan rancangan yang digunakan adalah Rancangan Acak Lengkap (RAL) dengan menggunakan 5 perlakuan (kontrol, perendaman biji selama 4, 8, 12, dan 16 jam) dan 6 ulangan. Setiap unit percobaan mendapatkan 30 biji tanaman gamal. Analisis data dilakukan dengan metode ANOVA dilanjutkan dengan uji beda nyata terkecil (BNT). Hasil penelitian menunjukkan bahwa skarifikasi biji gamal di dalam urin kambing dengan waktu berbeda memberikan hasil yang berbeda nyata $(\mathrm{P}<0,05)$ terhadap daya kecambah, kecambah normal, benih mati dan benih keras, tetapi tidak berbeda nyata $(\mathrm{P}>0,05)$ terhadap kecambah abnormal dan benih terserang hama. Perlakuan skarifikasi terbaik terhadap kecambah normal dan daya kecambah yaitu perendaman biji gamal di dalam urin kambing selama 16 jam, yaitu masing-masing 60,00\% dan 47,73\%. Hal ini menunjukkan semakin lama perendaman biji maka daya kecambah dan kecambah normal semakin tinggi.
\end{abstract}

Kata kunci: Biji gamal, Lama perendaman, Skarifikasi, Urin kambing 


\section{PENDAHULUAN}

Kekurangan pasokan pakan berkualitas di daerah tropis dengan musim kemarau yang panjang seperti Indonesia merupakan kendala utama produksi ternak. Alternatif untuk mengatasi masalah kekurangan bahan pakan ternak adalah dengan membudidayakan tanaman hijauan pakan ternak yang mampu beradaptasi dengan kondisi lingkungan yang kurang baik.

Tanaman gamal adalah nama jenis perdu dari kerabat polong-polongan (suku Fabaceae atau Leguminosae). Penyebaran alami tidak diketahui dengan jelas karena telah dibudidayakan sejak lama, tetapi bukti kuat menunjukkan bahwa penyebarannya terbatas pada hutan hujan tropis di dataran rendah pesisir Pasifik dan beberapa lembah pedalaman di Amerika Tengah dan Meksiko. Tanaman ini sekarang sudah menyebar di seluruh daerah tropika termasuk Indonesia (Direktorat Perbenihan Tanaman Hutan, 2002). Gamal (Gliricida sepium) adalah tanaman leguminosa pohon yang dapat tumbuh dengan cepat di daerah tropis sehingga dikatakan tanaman pakan ternak yang baik karena kemampuan produksinya tinggi dan kualitas hijauannya yang baik. Gamal sangat potensial dijadikan sumber pakan ternak karena mengandung protein yaitu $25,7 \%$, serat kasar $13,3 \%$, Abu $8,4 \%$ dan BETN 4,0\% (Hartadi et al., 1993).

Pemanfaatan daun gamal sebagai pakan ternak sangat menguntungkan, cara penanaman yang mudah, kandungan protein yang tinggi, masih tetap berproduksi baik meskipun musim kemarau, memperbaiki kesuburan tanah baik dari guguran daun maupun perakarannya, dan banyak lagi manfaat dari penanaman pohon gamal ini (Badan Ketahanan Pangan Provinsi Sumatera Barat, 2015).

Biji Gamal memiliki kulit biji yang keras. Tanaman ini juga memiliki dormansi yang cukup tinggi. Salah satu upaya untuk melestarikannya yaitu melakukan pengelolaan dan pembudidayaan yang tepat. Perlakuan biji sebelum tanam merupakan tahapan penting mengingat kulit biji yang keras merupakan faktor pembatas terhadap masuknya air dan oksigen ke dalam biji dan menyebabkan biji sulit berkecambah. Kulit biji yang keras membuat air sulit untuk menembus dan oksigen yang sangat penting dalam proses perkecambahan sulit untuk masuk (Hassen et al., 2004).

Perlakuan sebelum penanaman sangat diperlukan. Skarifikasi merupakan salah satu upaya pretreatment atau perlakuan awal pada benih yang ditujukan untuk mematahkan dormansi dan mempercepat terjadinya perkecambahan benih yang seragam (Schmidt, 2000). Biji Gamal yang diskarifikasi diduga akan berkecambah lebih baik dibandingkan dengan benih yang tidak diskarifikasi.

Pengujian benih dilakukan dalam rangka mengurangi resiko kegagalan pada saat memperhitungkan kebutuhan bibit di lapangan, dengan membandingkan banyaknya jumlah kecambah yang tumbuh terhadap benih yang dikecambahkan. Penelitian ini bertujuan untuk mengetahui pengaruh perlakuan lama perendaman terhadap daya perkecambahan benih tanaman gamal.

\section{MATERI DAN METODE}

\section{Waktu dan Tempat}

Penelitian ini dilaksanakan pada Januari-Februari 2020, berlokasi di Laboratorium Nutrisi dan Makanan Ternak, Jurusan Peternakan, Fakultas Pertanian, Universitas Lampung.

\section{Materi}

Alat yang digunakan dalam penelitian ini antara lain adalah kain kassa, nampan, kertas merang, gelas ukur, plastik, alat tulis dan stopwatch. Bahan penelitian yang digunakan antara lain adalah benih gamal yang dibeli di toko bibit tanaman Rizquna Kota Kediri dan urin kambing.

\section{Metode}

Penelitian ini menggunakan metode eksperimen dan Rancangan Acak Lengkap (RAL) dengan menggunakan 5 perlakuan dan 6 ulangan. Setiap unit percobaan mendapatkan 30 biji tanaman gamal. Sebelum dilakukan perendaman menggunakan urin kambing, seluruh biji gamal terlebih dulu diberi perlalukan perendaman selama 1 menit menggunakan air untuk mengoleksi biji yang baik dan menyingkirkan biji yang tidak baik untuk diskarifikasi. Perlakuan yang dilakukan yaitu P0 : tanpa perlakuan (kontrol), P1 : direndam dalam urin kambing selama 4 jam, P2 : direndam dalam urin kambing selama 8 jam, P3 : direndam dalam urin kambing selama 12 jam, P4 : direndam dalam urin kambing selama 16 jam.

\section{Parameter yang Diamati}

Parameter dalam penelitian ini adalah Presentase daya kecambah, kecambah normal, abnormal, benih terserang hama, benih keras dan benih mati. 


\section{Analisis Data}

Data yang diperoleh dianalisis dengan analisis ragam (analysis of variance, ANOVA) dan jika memberikan hasil yang nyata akan dilanjutkan dengan uji beda nyata terkecil (BNT) taraf 5\% dan 1\% (Steel dan Torrie, 1991).

\section{Pengaruh Perlakuan Lama Perendaman Benih terhadap Daya Kecambah Gamal}

Berdasarkan hasil analisis ragam pada Tabel 1, perlakuan skarifikasi memberikan pengaruh sangat nyata $(\mathrm{P}<0,01)$ terhadap daya kecambah gamal.

\section{HASIL DAN PEMBAHASAN}

Tabel 1. Daya kecambah biji gamal

\begin{tabular}{cccccc}
\hline \multirow{2}{*}{ Ulangan } & \multicolumn{5}{c}{ Perlakuan } \\
\cline { 2 - 5 } & P0 & P1 & P2 & P3 & P4 \\
\hline & $----------------------------------------(\%)------------------------------$ \\
\hline & 13.33 & 30.00 & 16.67 & 53.33 & 66.67 \\
3 & 10.00 & 23.33 & 0.00 & 30.00 & 46.67 \\
4 & 0.00 & 43.33 & 33.33 & 50.00 & 73.33 \\
5 & 0.00 & 13.33 & 36.67 & 43.33 & 56.67 \\
6 & 16.67 & 23.33 & 46.67 & 36.67 & 46.67 \\
\hline Rata-rata & 20.00 & 3.33 & 23.33 & 20.00 & 70.00 \\
\hline
\end{tabular}

Keterangan : Keterangan superskrip yang berbeda pada tabel menunjukkan hasil yang berbeda sangat nyata $(\mathrm{P}<0.01)$ berdasarkan uji beda nyata terkecil (BNT)

Berdasarkan uji lanjut BNT perlakuan mempunyai hasil yang berbeda, kecuali perlakuan P0 dan P1 yang menunjukkan hasil yang sama. Pada uji BNT perlakuan terbaik dengan daya kecambah tertinggi didapat pada perlakuan P4 yaitu dengan perendaman biji di dalam urin kambing selama 16 jam yaitu dengan nilai rata-rata daya kecambah sebesar $60,00 \%$, sedangkan daya kecambah terendah didapat pada P0 yaitu tanpa perlakuan. Pada perlakuan P0 ini memiliki nilai rata-rata daya kecambah sebesar $10,00 \%$. Hal ini menunjukkan bahwa perlakuan skarifikasi lebih efektif meningkatkan daya kecambah, dan urin kambing berpengaruh dalam meningkatkan daya kecambah biji Gamal. Hal ini sesuai dengan penelitian sebelumnya Nasution (2014), perlakuan perendaman benih biwa dalam urin hewan berpengaruh nyata terhadap percepatan perkecambahan dan pertumbuhan bibit pada parameter volume akar, umur berkecambah, dan jumlah daun. Serta menurut Hassen et al. ( 2004), skarifikasi lebih efektif memecahkan dormansi benih, sehingga akan meningkatkan daya kecambah.

Perlakuan ini telah membuktikan bahwa urin kambing dapat menjadikan kulit biji mengembang dan mudah lunak sehingga terjadi imbibisi air yang menyebabkan tumbuhnya kecambah. Hal tersebut sesuai dengan pendapat Prawiranata et al. (1981) yang mengemukakan bahwa perendaman urin dapat mempengaruhi perkecambahan benih berdasarkan lama waktu perendaman. Apabila lama waktu perendaman yang sesuai dengan keadaan kulit biji maka perkecambahan benih yang dorman dapat didorong dengan memeberikan zat pengatur tumbuh seperti auksin, sitokinin dan giberelin. Urin ternak salah satu substrat organik yang mengandung auksin dan giberelin, sehingga proses skarifikasi ini akan mempengaruhi perkecambahan untuk mempercepat proses perkecambahan pada benih yang berkulit keras.

Berdasarkan perlakuan perendaman biji gamal di dalam urin kambing dalam hal ini adalah di dalam urin kambing terdapat hormon giberilin dan auksin yang mampu meningkatkan pertumbuhan kecambah, karena hormon giberilin dan auksin berperan dalam mendorong aktivitas enzim glukoneogenik pada fase awal perkecambahan biji. Hal ini menjamin konversi yang cepat dari lipid menjadi sukrosa yang berguna untuk pertumbuhan dan perkembangan embrio menjadi kecambah. Disamping itu juga hormon giberilin juga dapat mendorong enzim hidrolitik kemudian berdifusi ke endosperm dan merubah molekul yang disimpan di endosperm menjadi gula dan asam amino. Zat ini dapat menjamin pertumbuhan embrio biji. Hal ini sesuai dengan hasil penelitian (Endang, 1995) yang menyatakan bahwa perendaman benih aren didalam larutan giberilin pada urin sapi yang mengandung senyawa giberilin dan auksin berpengaruh dalam meningkatkan daya kecambah. Giberilin dan auksin yang terdapat 
dalam larutan urin sapi yang mampu mengaktifkan enzim hidrolitik di dalam benih sehingga enzim hidrolitik dapat melakukan fungsinya dalam penyusunan dan perombakan zat makanan untuk pertumbuhan tanaman.

Pengaruh Perlakuan Lama Perendaman Benih terhadap Kecambah Normal Gamal

Tabel 2. Kecambah normal biji gamal (Gliricida sepium)

\begin{tabular}{cccccc}
\hline \multirow{2}{*}{ Ulangan } & \multicolumn{5}{c}{ Perlakuan } \\
\cline { 2 - 5 } & P0 & P1 & P2 & P3 & P4 \\
\hline & $-----------------------------------------------(\%)----------------------------------$ \\
\hline & 3.33 & 13.33 & 10.00 & 36.67 & 53.33 \\
3 & 0.00 & 10.00 & 0.00 & 23.33 & 33.33 \\
4 & 0.00 & 26.67 & 16.67 & 36.67 & 63.33 \\
5 & 0.00 & 6.67 & 26.67 & 26.67 & 36.67 \\
6 & 3.33 & 13.33 & 20.00 & 26.67 & 36.67 \\
\hline Rata-rata & 3.33 & 3.33 & 10.00 & 6.67 & 63.33 \\
\hline
\end{tabular}

Keterangan : Keterangan superskrip yang berbeda pada tabel menunjukkan hasil yang berbeda sangat nyata $(\mathrm{P}<0.01)$ berdasarkan uji beda nyata terkecil (BNT)

Berdasarkan uji lanjut BNT, P0 dan P1 menunjukkan hasil yang sama, namun berbeda dengan P2, P3 maupun P4. Pada uji BNT diperoleh perlakuan terbaik dengan kecambah normal tertinggi didapat pada perlakuan P4 yaitu dengan perendaman biji di dalam urin kambing selama 16 jam yaitu dengan nilai ratarata daya kecambah sebesar 47,78\%, sedangkan daya kecambah terendah didapat pada P0 yaitu tanpa perlakuan. Pada perlakuan P0 ini memiliki nilai rata-rata daya kecambah sebesar $1,67 \%$.

Hasil penelitian pada Tabel 2 menunjukkan bahwa nilai kecambah normal pada setiap perlakuan dipengaruhi oleh jumlah benih mati yang dihasilkan, seperti pada perlakuan P0 ulangan ke-2, ke-3 dan ke-4, serta pada perlakuan P2 ulangan ke-2 persentase kecambah normalnya sebesar $0,00 \%$, hal ini bukan semua benih pada perlakuan tersebut $100 \%$ abnormal, melainkan $100 \%$ benih yang dihasilkan merupakan benih yang busuk atau benih mati. Rataan kecambah normal biji gamal berkisar antara 1,67\% sampai 47,78\%. Jumlah kecambah normal pada penelitian ini masih rendah dimana kecambah normal yang dihasilkan paling tinggi hanya 47,78\%, masih di bawah 85\%. Hal ini disampaikan oleh Polpoke (2013), standar benih yang baik menghasilkan daya kecambah minimal $80 \%$ dan kecambah normal minimal $85 \%$, artinya benih yang tumbuh dari benih yang ditanam minimal $80 \%$, dan benih yang tumbuh secara normal minimal $85 \%$.

\section{Pengaruh Perlakuan Lama Perendaman Benih terhadap Kecambah Abnormal Gamal}

Berdasarkan hasil analisis ragam pada Tabel 3, perlakuan lama perendaman memberikan pengaruh nyata $(\mathrm{P}<0,05)$ terhadap kecambah abnormal biji gamal.

Tabel 3. Kecambah abnormal biji gamal

\begin{tabular}{|c|c|c|c|c|c|}
\hline \multirow[t]{2}{*}{ Ulangan } & \multicolumn{5}{|c|}{ Perlakuan } \\
\hline & $\mathrm{P} 0$ & P1 & $\mathrm{P} 2$ & P3 & $\mathrm{P} 4$ \\
\hline \multicolumn{6}{|c|}{ 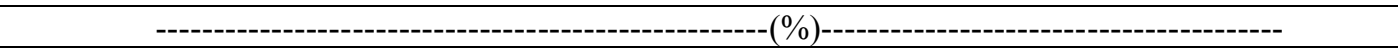 } \\
\hline 1 & 3.33 & 10.00 & 3.33 & 6.67 & 10.00 \\
\hline 2 & 6.67 & 10.00 & 0.00 & 3.33 & 6.67 \\
\hline 3 & 0.00 & 6.67 & 10.00 & 6.67 & 3.33 \\
\hline 4 & 0.00 & 3.33 & 6.67 & 10.00 & 6.67 \\
\hline 5 & 6.67 & 10.00 & 13.33 & 6.67 & 6.67 \\
\hline 6 & 10.00 & 0.00 & 10.00 & 6.67 & 3.33 \\
\hline Rata-rata & $4.44 \pm 4.04$ & $6.67 \pm 4.22$ & $7.22 \pm 4.91$ & $6.67 \pm 2.11$ & $6.11 \pm 2.51$ \\
\hline
\end{tabular}


Berdasarkan uji lanjut BNT diperoleh hasil yang tidak berbeda nyata $(\mathrm{P}<0,05)$ pada rata-rata perlakuan. Perlakuan $\mathrm{P} 0, \mathrm{P} 1, \mathrm{P} 2, \mathrm{P} 3$ dan P4 menunjukkan hasil yang sama. Hal ini mengartikan bahwa biji gamal yang direndam menggunakan urin kambing dengan waktu perendaman yang berbeda tidak ada pengaruh terhadap kecambah abnormal, namun jumlah ini mungkin akan berbeda jika lama waktu pengamatan untuk perkecambahan ditambahkan lagi, sebagaimana dalam penelitian sebelumnya menurut Rahayu (2015), bahwa kecambah abnormal yang terdapat pada setiap ulangan masih berpotensi untuk menjadi kecambah normal, namun keterlambatan imbibisi mengakibatkan lambatnya pertumbuhan kecambah sehingga di akhir pengamatan masih belum dapat dikategorikan sebagai kecambah normal.

\section{Pengaruh Perlakuan Lama Perendaman Benih terhadap Benih Terserang Hama Gamal}

Berdasarkan hasil analisis ragam pada Tabel 4, perlakuan lama perendaman memberikan pengaruh nyata $(\mathrm{P}<0,05)$ terhadap benih terserang hama biji gamal.

Tabel 4. Benih terserang hama

\begin{tabular}{|c|c|c|c|c|c|}
\hline \multirow[t]{2}{*}{ Ulangan } & \multicolumn{5}{|c|}{ Perlakuan } \\
\hline & $\mathrm{P} 0$ & $\mathrm{P} 1$ & $\mathrm{P} 2$ & P3 & $\mathrm{P} 4$ \\
\hline \multicolumn{6}{|c|}{-------------------------------------------------------------(\%) } \\
\hline 1 & 6.67 & 6.67 & 3.33 & 10.00 & 3.33 \\
\hline 2 & 3.33 & 3.33 & 0.00 & 3.33 & 6.67 \\
\hline 3 & 0.00 & 10.00 & 6.67 & 6.67 & 6.67 \\
\hline 4 & 0.00 & 3.33 & 3.33 & 6.67 & 13.33 \\
\hline 5 & 6.67 & 0.00 & 13.33 & 3.33 & 3.33 \\
\hline 6 & 6.67 & 0.00 & 3.33 & 6.67 & 3.33 \\
\hline Rata-rata & $3.38 \pm 3.28$ & $3.38 \pm 3.90$ & $5.00 \pm 4.59$ & $6.11 \pm 2.51$ & $6.11 \pm 3.90$ \\
\hline
\end{tabular}

Berdasarkan uji lanjut menggunakan BNT diperoleh hasil tidak berbeda nyata $(\mathrm{P}<0,05)$ pada rata-rata perlakuan. $\mathrm{P} 0, \mathrm{P} 1, \mathrm{P} 2$, P3 dan P4 menunjukkan hasil yang sama, yang artinya bahwa biji gamal yang direndam menggunakan urin kambing dengan waktu perendaman yang berbeda tidak berpengaruh terhadap benih terserang hama. Pada peneitian ini benih yang terserang hama pada biji gamal diakibatkan oleh adanya jamur. Menurut Schmidt (2000), tumbuhnya jamur pada benih dapat mengakibatkan penurunan daya kecambah, perubahan warna, kenaikan suhu dan kelembaban di dalam benih, perubahan susunan kimia dindalam benih dan produksi mikitoksin di dalam benih. Kondisi benih yang terbuka penyebab serangan jamur pada benih, sehingga pada benih yang rusak banyak terlihat spora dan dapat menular pada benih lain.

\section{Pengaruh Perlakuan Lama Perendaman Benih terhadap Benih Mati Gamal}

Berdasarkan hasil analisis ragam pada Tabel 5, perlakuan lama perendaman memberikan pengaruh nyata $(\mathrm{P}<0,05)$ terhadap benih mati gamal.
Berdasarkan uji lanjut BNT diperoleh hasil yang berbeda nyata $(\mathrm{P}<0,05)$ pada ratarata perlakuan. $\mathrm{P} 0$ dan $\mathrm{P} 1$ menunjukkan hasil yang sama, berbeda dengan P2 dan P3 yang menunjukkan hasil yang sama, dan berbeda dengan P4. Pada penelitian ini benih mati tertinggi didapat pada perlakuan P0 yaitu tanpa perlakuan, sedangkan benih benih mati terendah didapat pada perlakuan P5 yaitu biji gamal yang direndam dalam urin kambing selama 16 jam. Hal ini menunjukkan bahwa skarifikasi berpengaruh terhadap benih mati, yang mana pada P0 yaitu tanpa perlakuan menghasilkan benih mati tertinggi. Hasil ini sesuai dengan penelitian Kustyorini et al. (2017) yang menyatakan bahwa pada perlakuan P0 memberikan nilai persentase benih mati terbesar dikarenakan tidak adanya suatu proses yang membantu pemecahan benih pada saat proses perkecambahan. Selain itu menurut Nasution (2014) perlakuan perendaman benih biwa dalam urin hewan berpengaruh nyata terhadap percepatan perkecambahan dan pertumbuhan bibit, sehingga jumlah benih mati biji tanpa perlakuan menghasilkan jumlah yang paling banyak. 
Tabel 5. Benih mati biji gamal

\begin{tabular}{cccccc}
\hline \multirow{2}{*}{ Ulangan } & \multicolumn{5}{c}{ Perlakuan } \\
\cline { 2 - 5 } & P0 & P1 & P2 & P3 & P4 \\
\hline & $--------------------------------------------------(\%)----------------------------------------$ \\
\hline & 80.00 & 70.00 & 83.33 & 46.67 & 33.33 \\
3 & 86.67 & 76.67 & 100.00 & 70.00 & 53.33 \\
4 & 90.00 & 56.67 & 66.67 & 50.00 & 26.67 \\
5 & 96.67 & 86.67 & 63.33 & 56.67 & 43.33 \\
6 & 80.00 & 76.67 & 53.33 & 63.33 & 53.33 \\
\hline Rata-rata & $85.56^{\mathrm{c}} \pm 6.89$ & $77.22^{\mathrm{c}} \pm 13.73$ & $73.89^{\mathrm{b}} \pm 16.52$ & $61.11^{\mathrm{b}} \pm 12.59$ & $40.00^{\mathrm{a}} \pm 11.74$ \\
\hline
\end{tabular}

Keterangan : Keterangan superskrip yang berbeda pada tabel menunjukkan hasil yang berbeda nyata $(\mathrm{P}<0.05)$ berdasarkan uji beda nyata terkecil (BNT)

\section{Pengaruh Perlakuan Lama Perendaman Benih terhadap Benih Keras Gamal}

Berdasarkan hasil analisis ragam pada Tabel 6, perlakuan lama perendaman tidak memberikan pengaruh nyata $(\mathrm{P}>0,05)$ terhadap benih keras gamal.

Tabel 6. Benih keras biji gamal

\begin{tabular}{|c|c|c|c|c|c|}
\hline \multirow[t]{2}{*}{ Ulangan } & \multicolumn{5}{|c|}{ Perlakuan } \\
\hline & P0 & P1 & $\mathrm{P} 2$ & P3 & P4 \\
\hline & ----------- & ------------' & (\%)--- & 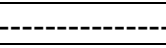 & --- \\
\hline 1 & 6.67 & 0.00 & 0.00 & 0.00 & 0.00 \\
\hline 2 & 3.33 & 0.00 & 0.00 & 0.00 & 0.00 \\
\hline 3 & 10.00 & 0.00 & 0.00 & 0.00 & 0.00 \\
\hline 4 & 3.33 & 0.00 & 0.00 & 0.00 & 0.00 \\
\hline 5 & 3.33 & 0.00 & 0.00 & 0.00 & 0.00 \\
\hline 6 & 0.00 & 0.00 & 0.00 & 0.00 & 0.00 \\
\hline Rata-rata & $4.44^{\mathrm{a}} \pm 3.44$ & $0.00^{b} \pm 0.00$ & $0.00^{\mathrm{b}} \pm 0.00$ & $0.00^{\mathrm{b}} \pm 0.00$ & $0.00^{\mathrm{b}} \pm 0.00$ \\
\hline
\end{tabular}

Keterangan : Keterangan superskrip yang berbeda pada tabel menunjukkan hasil yang berbeda nyata $(\mathrm{P}<0.05)$ berdasarkan uji beda nyata terkecil (BNT)

Berdasarkan uji lanjut BNT diperoleh hasil yang berbeda nyata $(\mathrm{P}<0,05)$ pada ratarata perlakuan. Perlakuan P1, P2, P3, dan P4 menunjukkan hasil yang sama, namun berbeda dengan perlakuan $\mathrm{P} 0$. Berdasarkan uji lanjut BNT pada taraf nyata $5 \%$ benih keras tertinggi didapat pada perlakuan P0 yaitu tanpa perlakuan, sedangkan benih keras untuk perlakuaan lainnya tidak ada. Hal ini menunjukkan bahwa skarifikasi sebelum penyemaian dapat menghilangkan jumlah benih keras. Hasil penelitian ini didukung oleh hasil penelitian Jawa et al. (2019) bahwa benih turi putih (Sesbania grandiflora L.) pada control memberikan hasil tertinggi pada benih kerasnya. Hal tersebut membuktikan bahwa benih yang diskarifikasi dapat memecah dormansi sehingga biji dapat berkecambah. Penelitian Juhanda et al. (2013) juga memperoleh hasil benih keras tertinggi benih saga manis (Abrus precatorius L.) pada benih tanpa perlakuan..

\section{KESIMPULAN}

Berdasarkan penelitian yang telah dilakukan dapat disimpulkan bahwa:

1. Lama perendaman biji gamal di dalam urin kambing memberikan hasil yang sangat berbeda nyata $(\mathrm{P}<0,01)$ untuk daya kecambah dan benih normal, serta berbeda nyata $(\mathrm{P}<0,05)$ untuk benih mati dan benih keras. Sedangkan untuk kecambah abnormal dan benih terserang hama memberikan hasil tidak berbeda nyata $(\mathrm{P}>0,05)$;

2. perlakuan skarifikasi terbaik untuk kecambah normal dan daya kecambah menunjukkan hasil yang sama yaitu pada perlakuan P4 perendaman biji gamal di dalam urin kambing selama 16 jam. 


\section{DAFTAR PUSTAKA}

Badan Ketahanan Pangan Provinsi Sumatera Barat. 2015. Database Ketahanan Pangan Provinsi Sumatera Barat. Padang

Direktorat Perbenihan Tanaman Hutan. 2002. Informasi Singkat Benih. Direktorat. Perbenihan Tanaman Hutan. Bandung

Endang, I. Y. 1995. Pengaruh Pemberian Giberilin Terhadap Perkecambahan Benih Pinang. Skripsi Fakultas Pertanian Universitas Jambi

Hartadi, H., S. Reksohadiprodjo, and A.D. Tillman. 1993. Tabel Kompsisi Pakan Untuk Indonesia. Universitas Gadjah Mada Press. Yogyakarta

Hassen A., P .A. Pieterse, and N . F. G. Rethman. 2004 . Effect of pre-planting seed treatment on dormancy breaking and germination of Indigofera accessi . Journal Tropical Grasslands 38 : 154 157

Jawa, M. A., S. K. Tatiek dan S. Memen. 2019. Uji daya berkecambah pada benih turi putih (Sesbania grandiflora L.). Departemen Agronomi dan Hortikultura, Fakultas Pertanian, Institut Pertanian Bogor. Jurnal Agrohorti 7(2): 130--137

Juhanda, N. Yayuk, dan Ermawati. 2013. Pengaruh skarifikasi pada pola imbibisi dan perkecambahan benih saga manis (Abruss Precatorius L.). Jurnal Agrotek Tropika. Vol 1(1): 45--49

Kustyorini, T. I. W. dan I. H. Permata. 2017. Perendaman benih pada berbagai suhu larutan urin sapi terhadap daya kecambah kaliandra (Calliandra
Calothyrsus). Jurnal Sains Peternakan Vol 6, No 1, Juni 2018, pp: 47-52

Nasution , L. Waidah. 2014. Percepatan Perkecambahan dan Pertumbuhan Bibit Biwa (Eriobotrya japonica Lindl.) Akibat Perendaman Pada Urin Hewan dan Pemotongan Benih. Skripsi Program Studi Agroekoteknologi. Fakultas Pertanian. Universitas Sumatera Utara. Medan

Prawiranata, W.,S., Harran, dan P. Tjondronegoro. 1981. Dasar-dasar Fisiologis Tumbuhan. II. Departemen Botani. Fakultas Pertanian Institut Pertanian Bogor, Bogor

Polpoke, Z. 2013. Kriteria Pemilihan Benih Bermutu. Departemen Pertanian. http://ditjenbun.Pertanian.go.id/bbpptpa mbon/berita-254-kriteriapemilihanbenih-bermutu-.html diakses 28 Februari 2020

Rahayu, A. D. dan T. K. Suharsi. 2015. Pengamatan uji daya berkecambah dan optimalisasi substrat perkecambahan benih kecipir [Psophocarpus tetragonolobus L. (DC)]. Jurnal Departemen Agronomi dan Hortikultura. Fakultas Pertanian, Institut Pertanian Bogor. Bul. Agrohorti 3 (1): $18-27$

Schmidt, L. 2000. Pedoman Penanganan Benih Tanaman Hutan Tropis dan Sub Tropis. Direktorat RLPS dan Danida Forest Seed Centre. Jakarta.

Steel, R. G. D. and J. H. Torrie. 1991. Principles and Procedures of Statistics (with Special Reference to the Biological Sciences). McGraw-Hill Book Company. New York. 